\title{
Assessment of Internal Migration Policies in Developing Countries: Evidence from Tanzania
}

\author{
Robert Ebihart Msigwa \\ School of Mathematical Sciences, Dalian University of Technology \\ PO box 116024, Linggong Road, Dalian, P. R. China \\ E-mail: msigwa77@gmail.com
}

Kembo M. Bwana

School of Accounting, Dongbei University of Finance and Economics

No.217, Jianshang Street, Dalian, P. R. China

E-mail: kembo211@gmail.com

Received: November 3, 2013 Accepted: November 23, 2013

doi:10.5296/ber.v4i1.5077ＵRL: http://dx.doi.org/10.5296/ber.v4i1.5077

\begin{abstract}
The objective of this study was to determine the relationship of national policy and internal migration with the aim to provide some useful determinants in developing migration policies in Tanzania. The study used the multinomial logistic regression model to examine the internal migration factors which are very important in developing migration policies. Secondary data extracted from the National Bureau of Statistics was used for analysis. The study found out that gender, wage differentials, level of education, marital status and age are significant factors in developing migration policy in Tanzania. The study also revealed that more single male with less education make more movements than female. The study suggests that the government and policy makers to review some laws and regulations governing migration. In addition, it suggests that before imposing any restrictive policy, the government authorities are recommended to develop policies that reflect opportunities available in the country with the aim to reduce the negative effects of migration.
\end{abstract}

Keywords: Internal migration, Policies assessment, Developing countries, Tanzania 


\section{Introduction}

For the past three decades, both developed and developing countries have witnessed unparalleled human migration within and across political and geographical boundaries. Several reasons have been contributing people to migrate, they include; poor socio-economic conditions, low wages, and high growth rate of unemployment and poverty. Apart from these reasons, other factors such as a mismatch between the population growth and availability of resources, poor advanced technology and capacity of governments to create jobs at the place of origin has played great role to influence migration decisions. In some regions, poor governance, patronage, corruptions, political instability and civil wars have facilitated the out-migration of skilled and unskilled workers. The low cost of migration, improved communication and information, the need to join relatives, spouses, families and friends have fuelled the out-migration in the world. The opportunities for a better life, high income and security, better quality of education and health care facilities at the destinations, for a long time has influenced people to decide to migrate even if they don't have clear information about the place of destination. In urban area unemployment rate and labour deficits can be observed seasonally while in rural areas there are under-utilization of labour resources which contributes to uneven distribution of income. Globalization process itself, has facilitated the movements of people within and across the boundaries of the African continent. With this in mind, it is clear that migration will continue to bring challenges to politicians, economists and pressure will be stiffer to policy makers about the future management of the migrants for the betterment of the African societies. In developing countries, income from internal migrants is recognized to be one of the sources of remittances for long time have been used for development in rural areas in terms of education and production when applied directly or indirectly via higher consumption levels. On the other side, internal migration from rural to urban areas has created a lot of pressure in the place of destinations because municipalities and councils may not be able to accommodate the large population inflows and provide adequate social services to satisfy the demand of the society. Inadequacy of governments to render services to satisfy the demand has facilitated to the formation of slums, has caused extreme cases of internal crimes and unrest by striking. The pressure caused by migrants has forced many governments to develop policies to restrict the movement of people from the place of origins. Some of these policies have shown to be effective to handle the pressure of migrants while others are fruitless. For example, Latin America and Kenya introduced the policies and programs of farms through land reformation and other mechanisms in order to redirect the flow of migrants to intermediate urban growth poles (industrialized areas) and new cities. Malaysia, Philippines and India also adapted resettlement scheme in attempting to reduce the population flow to urban areas (Simkins \& Wernstedt, 1971). The government of Ghana in 1970-1971 developed two major projects around Volta Dam (road construction and hydroelectric project) and Niger River (fishing project) with similar intentions. In Zambia between 1963-1969 and 1972-1976, the policy for rural road construction, schools and clinics building and other facilities were planned and invested by government in rural areas so as to reduce the outflows from rural area. Tanzania focused heavily on resettlement of rural residents in its program. The five year program of (1969-1974) introduced the resettlements of the landless 'wachagga' families from Moshi to Mwesi highlands. This program was followed by another in other regions which included 
obligatory movements of thousands of scattered farmers into nearby villages and new settlement area (Ujamaa villages). Villagisation and new settlements programs simplified the provision of services in rural areas such as the agricultural extension activities, hospitals and clinics; schools etc., at the same time reduced the outflows. However, the trade liberation, free labor market, downfall of food and cash crop prices, land degradation, deforestation, soil erosion, income differentials, poor education and health facilities and services, and unreliable rainfall in early 1980s forced the government to shut down all projects and programs leading to unemployment and economic crisis in the country. The collapse of public industry and parastatal organizations influenced people to migrate to urban areas seeking for better life and employment in private companies. The increase of migration in urban areas brought attentions to government of Tanzania to take some measures to reduce the outflows from rural areas. The government authorities decided to induce some policies to restrict massive migration from rural areas. Unfortunately the development of these policies based on adapting models with success in developing countries rather than considering the economy and reasons for migration within the country. The experiences show that policies to handle migrants in the country have big holes to reduce the negative effect caused by migrants and migration process.. As mentioned earlier some of these policies have shown fruitful results but otherS have caused some problems. Although, reasons for failure and success are not known to majority but strength of the country in terms of economy, resources and geographical environment can be used as a benchmark to develop suitable policies for managing migrants and migration process. . It is also important for a country experiencing high rates of migration to extend the scope of using models and policies that aim to answer the question of how and to what extend should the migration be tolerated or restricted in order to balance the effect of migrants in the country. Apart from that decision to use particular model must reflect the opportunities that influence migrants to migrate rather than applying the models and techniques which have shown success in other countries which might not be suitable to a country like Tanzania. Therefore, the objective of this paper is to utilize the simple multinomial logistic model to show some useful determinants which are very important for the development of migration policies in the country.

The remaining part of this paper is organized as follows. In section 2, a review of the literatures is given. In the next section, the methodology and data are presented. In the section 4, results and discussion are provided. Finally, concluding and recommendations are given in section 5.

\section{Review of the Literatures}

\subsection{Theoretical Literature Review}

Migration is a fundamental component of human rights policy which provides opportunity for freedom of movements and rights of residence. This component has been filed and accepted in the human right concepts which asserts a nation of state where the resident is present to leave the country or region, travel whenever the country or region is welcomed with proper documentation(if the movement is international) but sometime without proper documents when the movement occur within the country; return to the place of origin any time with equal and greater importance to travel to, reside in and/or work in any part of the country without 
violating the policies and regulations of the country and is respected in the constitution of several developed and developing countries (Africa-Europe Summit, 2000). The theoretical models relating rural-urban migration and policies are classified into three parts including; the dual economy models which appeared in the 1950s and 1960s, the Harris-Todaro model developed in the 1970s and 1980s and finally, models covers the microeconomics where much of the research has focused over past of 25 years (also known as New economics of labor migration) Lucas (1997). The first model presented by Lewis (1954) gives some description about the transition of stagnated economy on a tradition sectors to a growing economy driven by the development of the modern urban sectors. However, in the real world the application of the model is weak because the growth of the economy of any country does not depend only on the accumulation of the capital in modern industry but there are other factors contributing to the growth. The policy implication of this model encourages government experiencing transition of labor from a labor intensive agricultural economy to significant industries and service sectors economy to allow migration of labours. Harris-Todaro (1971) model attempted to link internal migration and existence of unemployment in urban areas. This model leads to paradox with the fact that policies targeting to increase number of jobs in a particular city are likely to decrease employment due to induced migration. The development of this model was based only on the expected income differentials and leaving other elements influencing migration untouched (Katz \& Stark, 1986a). The empirical evidence of this statement is based on the fact that the migration can occur even when the urban expected income is below the rural income. The policy implication of the model encouraged government authorities to develop policies that restrict rural-urban migration and it is from this model where many developing countries have developed policies governing migration process. The extension of Lewis and Harris-Todaro models is the new economic models of labor migration which allow the inclusion of the rural sectors in the analysis. This model appears in the study conducted by Khandler \& Rashid (1994) which argued that since there are surplus of labor in agriculture; workers should be paid according to the average product. Fields (1975) made some modification of the existing models by including the urban job search from the rural area workers which were overlooked in the previous estimation of unemployment rate. The policy implication of this model recommends government to allow migrants in a job search framework so that migrants can make suboptimal choices rather than leaving them with imperfect information about the labour market. This programs more important in matching urban jobs and rural migration as appeared in the Qumbu mountain project in China. The policy implication of this model also suggests that the focus of countries should be to invest in rural areas where the population and migration to urban is very high(Ping \& Pieke, 2003). However, in doing so it is important to develop policies which target to rescue poor families living in rural areas because some of these families have no migrant members who can send remittances to them. Unless these families will not be able to escape from poverty and win whatever opportunity appeared in the labour market.

\subsection{Empirical Literature Review}

Apart from the theoretical literatures, there are a wide range of empirical studies relating rural-urban migration and policies in the developing countries. Widjojo (1970) studied a very 
long standing project among the Indonesian which aimed to direct the Javanese to the outer Islands. The project of resettlement scheme started in 1930s, failed miserably to attract people because the plan to investigate soil conditions and land use plan were not considered with the government authorities which led to grave misfortune to incoming settlers. The project resumed 20 years later with another vision to create employment to Java's landless peasants. The second project also failed, reasons for failure are several including; poor organizations, shortage of irrigation schemes and poor transportation facilities (Wertheim, 1964). Malaysian resettlement project of emergency appeared in the report of Sandhu (1964) noted that the project displaced thousands of rural settlers and those enclosed behind the barbed wire for the duration of rebellion reduced the guerrilla's peasant base. The successes of this project create another problem of urbanization in the region. Lee (1970) provided some useful information about the situation occurred in Sarawak area where the government decided to resettle Dayaks into viable economic units. Similar programs were introduced in Thailand; the project was fruitful but the problems of uneven distribution and rapid population growth emerged in the area. $\mathrm{Ng}$ (1968) explained that state-sponsored land settlement projects were necessary in bringing relief to the congested area and in averting the danger of massive migration to the cities. Such a projected initiated in Philippines started in Mindanao area bared no fruits while similar project implemented in Sri-Lanka were very successful (Zachariah, 1969). Lavell (1972) studied the indirect effects of hydroelectric power generated at the sites in Philippine noticed the attraction of large dynamic industries in the areas. Author also found that attract of large industries influenced inflow of migrants from a perennial source of Philippine manpower. Burke (1970) presented evidence indicating that the Bolivian population has increased from 50 to $100 \%$ since the land reform program begin in 1953 . He noted that in spite of natural increase in population in this ex-estate, there has been a substantial migration to these lands from the indigenous communities, villages and cities. Cuba in 1964 focused to slow population growth from the migration by building more cities, scattered rural people were settled in towns with a broader range of improved services and urban areas throughout the nation and the outfitted areas were to serve as ports or manufacturing locations (Acosta \& Hardoy, 1972). Housing construction started in Venezuela was among the successful project (MacDonald, 1968). A report from this study found that about 50000 of dwellers houses were constructed in 1965 which shifted the mind of rural migrants not to migrate by $45 \%$ and $9 \%$ of people stated to benefit directly from the rural housing plan. Urzua (1975) attempted to investigate the contribution of colonization schemes in the rural-urban migration in the territories of colonization. The aim of the study intended to see whether colonization schemes were successful in retaining the settlers or slowed migration to the large urban centers. He found that the migration rate depends on the amount of technical and financial support they received. For example in Bolivia, a major colonization program operated in the country since 1962 increased the agricultural production and prevented outflow of migrants because in some zones colonialists provided some temporary homes, livestock, and tools, limited amount of credit, schools and health and clinical services. However, unforeseen problems emerged after harvest in which inadequate marketing mechanism for the bumper crops production and poor roads to cities forced people to seek another alternative to get income to sustain life. In 1970, Jakarta government imposed policies to migrants that demanded them to register and deposit their 
return fare; the policy was unsuccessful because of vagrancies and unlicensed hawkers who were transported out of the city returned to the city (Simmons, 1981). In South Africa job permits, settlement restrictions and curfews used to restrict movements of the black population reach designated areas for whites. Despite the willingness of the South African government and police to use extreme measures including destruction of unapproved housing and forcible relocation to the homelands, migration has persisted even without this context. Communist introduced in China demanded the movement certificates from place of origin, proper documentation of job offers, check points in the transport systems and other mechanisms to restrict rural-urban migration.

Oberai (1983) stated that during the period of 1969 and 1973, 10 to 15 million urban secondary school leavers were resettled in rural areas in developing countries. Henderson (1986) noted higher urban earnings significantly attract more migrants. He noted that effective mechanisms affecting take home pay depends upon the source of downward wage rigidity because reducing the real minimum wage or public sector pay in any context is difficult due to the increase nominal levels in the face of inflation. On the other hand, it is not clear whether the minimum wage laws are the effective technique in preventing wage flexibility and enforcement from uniform to the extent that urban migration is based especially for skilled workers. In addition, the minimum wage may not be binding migrants where collective bargaining is the major source of the rural-urban wage gap but regulating the collective bargaining process may prove effective in restraining urban wage pressures (Becker, Mills, \& Williamson, 1986). Findley (1981) used two sets to distinguish rural development strategies. The first set comprised many elements which proved to reduce the demand for agricultural laborers, subsidized, mechanization, research and development of labor, displacing crop type pricing policies and favoring each cash crop, commercial farming and irrigation schemes which favoured larger farmers and ignoring the small scale farmers. Findley also stated that some of these elements have stimulated the out-migration either to town or to other rural areas. Author suggested that it is important to consider the employment creation, human resources and integration of the rural development scheme upon out-migration in order to overcome the outflow of laborers. A similar study conducted by Varayana, Darikh, \& Srinivas (1988), aimed to investigated whether rural development schemes should be integrated or judge only by their effects to out-migration. The study noted that rise in rural men's income may principally serve to finance more migration to urban areas. Wheaton \& Shishido (1981) examined the cross-country population concentration (measured by the square of the city relative to total population) patterns in the city against non-agricultural GNP per capita (interpreted as a proxy for market size). The authors found that concentration at first rise, then declines as income increases which becomes difficult to interpret the findings in terms of agglomeration externalities because the actual concentration failed to be optimized with respect to these effects at every level of development and the question about whether per capita or absolute incomes should be used as proxies for market size or domestic market alone is relevant to the open economies. Henderson (1986) presented the evidence of estimated cost functions for several manufacturing industries in Brazil, the result indicated that the costs decline to the level of employment in the same industries in the same location, but never declined with respect to local population. This implies that economies are driven by within industry production 
externalities rather than by the size of local market or other benefits of urban size. Results from this study were consistent with those obtained by Modi (1982) in the study conducted in low developed countries (LDCs).

Hugo (1981b) used the case study of Indonesia to examine the effect of improved road and concluded that transportation probably has increased the circular migration and the extent of population mobility while discouraging the long distance permanent movements. Recent analysis of the interaction between the migration and infrastructure in the developing country context is that of Rosenzweig \& Wolpin (1988) which pointed the benefits of subsidizing local public programs. A program of subsidizing tends to attract families with high propensities to spend on children, but this may be either in the form of higher fertility or expenditure per child. Moreover, subsidizing family with 'public' good inputs also have a tendency to attract families with higher propensities to spend but in this case, the benefits are not diluted by lower family size, larger families and those tending to spend more per person are attracted. The effects of rural education upon departure focus upon quantity rather than quality or context of education, whereas the important decision at the margin may be to invest in upgrading the quality (Behrmars \& Birdsall, 1983). Indeed, in response to the induced rural-urban migration, a number of developing countries have designed rural vocational curricular in the hope of raising productivity in agriculture relative town production, as well as changing notions regarding life in rural. Some authors argued that even conventional primary schooling can raise productivity in agriculture (Lockheed, Janison, \& Lau, 1980a; Findley, 1981). Speare \& Harris (1986) noted that in Indonesia rural-urban migration among post-primary education were very high and stated that it wrong to interpret the results based on relative earnings alone. The authors suggested that this may simply reflect the skill mix of jobs created in town, resulting in migration of better educated without necessary raising their rural-urban earnings differentials. Although, literatures mentioned above covers all angles of migration process, yet there are some weaknesses in linking internal migration and development of migration policies. In Tanzania, there have been several attempts to reduce the rural-urban migration through the development initiatives in the intermediate town (Mbonile, 1994b). The history of the villagisation program introduced in the country during the Arusha declaration (1967) and after the declaration, twisted the mind policy makers to believe that development and provision of good social services in rural area were the only solution to intervene rural-urban migration. At the beginning programs were successful in agriculture and education sector, however, the economic liberation and free trade in 1980s forced people to move from rural to urban. This movement reduced the tendency of sending remittance to their origin places rather they opted to invest nearby town. The negative effects of migration has forced government authorities to introduce some strong policies to reduce rural-urban migration but challenge remain in looking the livelihood strategy in the area of public policy. The scope of the policy makers is to reduce the inflow to urban areas rather than considering the volume and effect of restricting migrants in relation to the economy of the country. For example, in Tanzania poverty reduction strategy paper (PRSP) never mentioned anything about migration process and migrants welfare. It is known that well managed migration has significant benefits in the origin and destination regions. Despite of several studies about migration process in the country, there are some unfilled gaps in literatures linking internal migration and development of policies governing 
migration process and migrants welfare. Therefore, understanding and developing appropriate policy about migration are of great importance in the country because the mismanagement or unmanaged migration has serious consequences (such as regional security and jeopardizing inter-regional relations) in the country and well-being of migrants. Mismanagement of migration is known to cause unnecessary conflict between the host communities and migrants such as xenophobia, discrimination and other social pathologies. This study gives important information to policy makers and stakeholders to understand the magnitude and determinants of migration to be considered during the development of policies, programs and projects which aim to reduce rural-urban migration. Therefore, the aim of this paper is to examine determinants of internal migration necessary for linking migration and development of migration policies in Tanzania.

\section{Methodology and Data}

The objective of this paper is to assess the internal migration policy framework in Tanzania. This paper uses the multinomial logistic regression (MNL) to show the relationships between non-metric dependent variables and metric or dichotomous independent variables. Multinomial logistic regression compares multiple groups through a combination of binary logistic regressions. The groups of comparisons are equivalent to the comparisons for a dummy-coded dependent variable, in which the group with the highest numerical scores are used as the reference group. Multinomial logistic regression analysis requires the dependent variable to be non-metric such as dichotomous, nominal and ordinal variables which satisfy the level of measurement required. Multinomial logistic analysis requires independent variables to be metric or dichotomous. The overall test of the relationship between the independent variables and the group defined by dependent variable is based on the reduction of likelihood values for a model which does not contain any independent variables and the model that contains the independent variables. Therefore, the relationship between the dependent variable and the combination of the independent variables is based on the statistical significance of the final model of Chi-squire(Model Fitting Information). A multinomial logistic regression does not compute the correlations to estimate the strength of the relationship (Pseudo R, square measure such as Nagelkerke's $\mathrm{R}^{2}$ ) appeared in the analysis usually do not give significant information about the accuracy or errors associated with the model. In that case, the classification accuracy is used to compare the predicted group membership based on the logistic model to the actual known group membership which is the value for the dependent variable. The multicolonearity in the multinomial logistic regressions solution is detected by examining the standard errors for the regression coefficients. A standard error larger than 2.0 indicates numerical problems and should not be interpreted after analysis. This model is appropriate for this study because there are more than two categorical independent variables and the dependent variable of nominal/categorical falls under the dependent variable of a given set of the categorization which cannot be ordered in a meaningful way (Greene, 2003). The multinomial regression is a good example to illustrate an internal migration framework. The general multinomial logistic model is presented as follows; 


$$
\operatorname{Pr}\left(z_{i}=k\right)=\frac{e^{\alpha_{k} x_{i}}}{\sum_{k=1}^{K} e^{\alpha_{k} x_{i}}}
$$

$\mathrm{zi}_{\text {; }}$ presents the dependent variables over which the probability distribution is defined, $\mathrm{x}_{\mathrm{i}}$ indicates the set of explanatory variables of the model (gender, age, wage differentials, marital status and level of education), $\alpha$ denotes the regression coefficient and $\mathrm{k}$ is the possible number of outcomes. The dependent variable of the model is the migration status in Tanzania. According to the integrated labor force survey (2006) conducted in the country migrants are classified into two namely migrants and non-migrants. The possible outcomes from the model represent the probability of the individuals to stay or move under several demographic and household characteristics. The migrant status in the country is categorized into the rural-rural, rural-urban, town-city and international migration. The first three represent the internal migration whereas the last component represents the international migration. For the purpose of this study the first three categories were extracted from the data set of the Integrated Labour force survey of 2006, in order to obtain the data needed to determine the internal migration policies. Only rural-urban and town-city migration were used for analysis and rural-rural migration was not included in this study. The main reasons for not including rural-rural migration is small proportional of the movements within the country and this movement involves farmers and animal keepers whose data are not found in the database of the National Bureau of Statistics. This study has adopted the International Labor organization definition of migration which states that migrants are people moved (voluntarily or forced) from their original areas to other places either temporarily or permanently. The explanatory variables of the model include; gender, wage, age, marital status and level of education. All data used in this study were extracted from the Integrated Labor Force Survey (ILFS, 2006) which is the current labor force survey available as the 2011 survey was not conducted. The population that participated in this study are those economically active aged 15 years and above and it is estimated that in 2001 there were 19.2\% living in urban areas while in 2006 the number increased to $25.9 \%$ reflecting that the migration within the country has been increasing unforeseeable. Although, the number of males in some region has declined, the overall of females aged 10 years and above has remained stable over the period 2001 and 2006 which is estimated to be $50.9 \%, 51.3 \%$ respectively.

Table 1. Summary of Statistics of Individual Decision of Migration

\begin{tabular}{|l|l|r|r|}
\hline \multicolumn{5}{|c|}{ Case Processing Summary } \\
\hline \multirow{3}{*}{ Individual status } & Migrants & $\mathrm{N}$ & Marginal Percentage \\
\cline { 2 - 4 } & Non-migrants & 39426.38 & $49.0 \%$ \\
\hline \multirow{3}{*}{ Gender } & Male & 41080.36 & $51.0 \%$ \\
\cline { 2 - 4 } & Female & 56385.67 & $70.0 \%$ \\
\hline \multirow{3}{*}{ Age Group } & $15-24$ & 24121.07 & $30.0 \%$ \\
\cline { 2 - 4 } & $25-34$ & 13982.47 & $17.4 \%$ \\
\cline { 2 - 4 } & $35-64$ & 24689.92 & $30.7 \%$ \\
\hline
\end{tabular}




\begin{tabular}{|c|c|c|c|}
\hline & $65+$ & 350.63 & $.4 \%$ \\
\hline \multirow[t]{4}{*}{ Marital status } & Single & 19463.15 & $24.2 \%$ \\
\hline & Married & 51796.92 & $64.3 \%$ \\
\hline & Widowed & 3524.04 & $4.4 \%$ \\
\hline & Divorced/Separated & 5722.62 & $7.1 \%$ \\
\hline \multirow[t]{4}{*}{ EDUCATION LEVEL } & Never Attended & 3828.60 & $4.8 \%$ \\
\hline & Primary Not Complete & 9445.08 & $11.7 \%$ \\
\hline & Primary Complete & 42242.69 & $52.5 \%$ \\
\hline & Secondary above & 24990.37 & $31.0 \%$ \\
\hline \multicolumn{2}{|l|}{ Valid } & 80506.74 & $100.0 \%$ \\
\hline \multicolumn{2}{|l|}{ Missing } & 38371320.75 & \\
\hline \multicolumn{2}{|l|}{ Total } & 38451827.49 & \\
\hline \multicolumn{2}{|l|}{ Subpopulation } & $175 \mathrm{a}$ & \\
\hline
\end{tabular}

Source (NBS-ILFS, 2006)

\section{Results and Discussion}

The analysis to assess the internal migration policy framework in this study was conducted based on the definition of the migration in order to make some comparisons and benchmark with similar studies in other countries applying the multinomial logistic model (MNL). Non-migrants are set as a reference and the estimation of the probability of migrants with particular characteristics are compared to non-migrants. First, the independent variable is tested to show whether there is a significant relationship to the dependent variable. This is quite important for determining the ability of the model to predict accurately the dependent variables from the initial model without including independent variables. Second five independent variables are added (gender, age, marital status, level of education and wage differentials between rural and urban) to the model in order to test whether the addition of independent variables shows some improvement in Chi-square. The results revealed that it is statistically significant between the dependent variables and the set of independent variables with Chi-square of 12228.418 with 12 degrees of freedom at the $5 \%$ level of significance (see, table 2). The tested result implied that the independent variables added to the model have strong relationship to the depend variable, which reduce the error contributed in the model and very accurately predict dependent variable of the model which reflect the migration status.

Table 2. Model testing

\begin{tabular}{|c|c|c|c|c|}
\hline \multicolumn{5}{|c|}{ Model Fitting Information } \\
\hline \multirow{3}{*}{ Model } & Model Fitting Criteria & \multicolumn{3}{|c|}{ Likelihood Ratio Tests } \\
\cline { 2 - 5 } & -2 Log Likelihood & Chi-Square & df & Sig. \\
\hline Intercept Only & 110330.93 & & & \\
\hline Final & 98102.511 & 12228.418 & 12 & 0.000 \\
\hline
\end{tabular}

Source (NBS-ILFS, 2006) 


\section{Ml Macrothink}

Business and Economic Research ISSN 2162-4860 2014, Vol. 4, No. 1

The overall contribution of the set of independent variables to the model was to test the significance of each independent variable to all over the relationship between the independent variables and the individual independent variables. All independent variables participated in this study were tested in order to examine their contribution to the reduction of error in the MNL measured by 2-log likelihood statistics. The likelihood ratio test results indicate that all the independent variables (gender, age, and marital status, level of education and wage of rural and urban) are statistically significant at the $5 \%$ level of significance (see, table 3). This suggests that all independent variables were significant variables in explaining the difference patterns occur in migration status in the studied model and the involvement of the model in the error reduction.

Table 3. Variable testing

\begin{tabular}{|c|c|c|c|c|}
\hline \multicolumn{5}{|c|}{ Likelihood Ratio Tests } \\
\hline \multirow[b]{2}{*}{ Effect } & \multirow{2}{*}{$\begin{array}{c}\text { Model Fitting Criteria } \\
-2 \log \text { Likelihood of Reduced Model }\end{array}$} & \multicolumn{3}{|c|}{ Likelihood Ratio Tests } \\
\hline & & Chi-Square & $\mathrm{df}$ & Sig. \\
\hline Intercept & 98102.511 & .000 & 0 & \\
\hline Wage in Urban & 98345.167 & 242.656 & 1 & .000 \\
\hline Wage in Rural & 100420.396 & 2317.885 & 1 & .000 \\
\hline Gender & 103745.008 & 5642.497 & 1 & .000 \\
\hline Age Group & 99117.263 & 1014.752 & 3 & .000 \\
\hline Marital status & 98124.948 & 22.437 & 3 & .000 \\
\hline Level of Education & 99381.849 & 1279.338 & 3 & .000 \\
\hline
\end{tabular}

Source (NBS-ILFS, 2006)

Table 4 indicates that gender (male), marital status (single), wages (rural and urban), age (except those aged 65+) are important determinants in internal migration. The level of education (not attended, primary not completed and primary completed) variables are statistically significant to distinguish migrants from non-migrants while for non-migrants wages and age variables are statistically significant.

Table 4. Migration status with reference to non-migrants

\begin{tabular}{|l|r|r|r|r|r|r|}
\hline \multirow{2}{*}{ Migrants of the Households } & \multicolumn{1}{|c|}{ B } & Std. Error & Wald & df & Sig. & Exp(B) \\
\hline Intercept & -17.467 & .041 & 179394.026 & 1 & .000 & \\
\hline Wage in Urban & .031 & .002 & 240.661 & 1 & .000 & 1.032 \\
\hline Wage in Rural & .000 & .000 & 1466.997 & 1 & .000 & 1.000 \\
\hline Male & 1.316 & .018 & 5274.958 & 1 & .000 & 3.728 \\
\hline $15-24$ & 16.548 & .028 & 343864.202 & 1 & .000 & 15373304.990 \\
\hline $25-34$ & 16.231 & .019 & 763017.535 & 1 & .000 & 11194518.393 \\
\hline $35-64$ & 16.034 & .000 & & 1 &. & 9194967.846 \\
\hline Single & .061 & .035 & 3.027 & 1 & .082 & 1.062 \\
\hline
\end{tabular}




\begin{tabular}{|l|r|r|r|r|r|r|}
\hline Married & -.039 & .031 & 1.625 & 1 & .202 & .961 \\
\hline Widowed & -.084 & .050 & 2.772 & 1 & .096 & .920 \\
\hline Never Attended & .906 & .042 & 456.182 & 1 & .000 & 2.475 \\
\hline Primary not Complete & 1.011 & .031 & 1069.673 & 1 & .000 & 2.748 \\
\hline Primary Complete & .481 & .020 & 561.558 & 1 & .000 & 1.618 \\
\hline
\end{tabular}

Source (NBS-ILFS, 2006)

Considering the role of each independent variable which differentiates the migrants from non-migrants we found that the independent variables of the model are significant. The results show that the migration of the males in Tanzania is $70 \%$ while that of females is $30 \%$. These results are consistent with findings reported by Hugo (1995) and Lin (1998) in a study conducted in Indonesia that gender is the key factors in determining the migration in countries experiencing high rate of migration. This study also noted that the migration favors men than women. Several reasons have been noted during the analysis that traditions, cultural and social practices discriminate women not to participate in the any economic decision of the family. Women in the country are left behind to care families and other housework. The results about the wage differentials between rural and urban are statistically significant although the amount may not reflect the reality because wage and income in the country is secret information. Although, the results may not reflect the reality but the gap in wages between rural and urban is known to attract more people to urban areas. With this in mind individuals from rural area opt to migrate to urban areas seeking for better employment and higher wage rather than engaging in agricultural production which depends on the rainfall that are not reliable with low selling price of the products. The migration to urban areas in the country is dominated by non-educated group and unskilled contrary to the demand of the labour market which require at least university or college education to be employed in decent work. The results are consistent with that presented by Mbonile (1996) in the country indicating that the migration rate from rural to urban is higher among those with less education. The case of marital status in differentiating migration reveals that single, married and divorced have slightly increase in the likelihood of migrants compared to those decided to stay by $24.2 \%, 64.3 \%$ and $7.1 \%$ respectively. For the married, divorced and widowed the migration favors males and leaving behind females who have some obligation of family caring and house work.

\section{Conclusions and Recommendations}

The objective of this study was to show linkage between the internal migration and policy development in Tanzania with the aim to providing useful information regarding the national policy and migration process in the country. Results from this study are useful to policy makers and stakeholders to understand the magnitude of the problem, to use appropriate determinants in developing policies, programs and projects that aim to reduce negative effect associated with migration both in place of origin and destination. Thus, this study uses the multinomial logistic regression model to obtain important determinants of internal migration necessary in developing migration policy which intends to answer the question of how and to what extent the migration should be tolerated or restricted. The dependent variable used in this study is the migration status which includes the rural-rural, rural-urban and town-city. In addition, the 
analysis carried in this study utilized secondary data extracted from the National Bureau of Statistics in the integrated labor force survey of 2006 which is the current survey in the country. Findings from the study conclude that the wage differentials between rural and urban, gender (male) and age are statistically significant to influence internal migration. The study recommends the the government of Tanzania develop policies and regulations that reflect the economy and migrants welfare in the country. In addition, the fundamental strategy suggested by this study is to make some amend of the laws governing the migration process and focus of the projects and programs must aim to favors non-migrants. The development of policies must aim to grab whatever the opportunities available in the region rather than adopting policies that seek to overcome the problem of the whole country because the nature of the regions and the reasons for movement differ from one individual to another within/across the regions. Furthermore, wage differentials can be managed by investing in rural areas and controlling the price of agricultural products which may help to discourage migrants to migrate. The experience shows that earnings from agriculture are enough to cover all expenses of basic needs perhaps with a surplus is a good technique to reduce the outflow to urban areas. It is also time for manpower agencies to be fair enough when dealing with job seekers who have graduated at different levels of education in terms of salary to pay them according to their professionalism. It is wise to include other employment incentive rather than taking advantage of the scarcity of jobs in the country by paying peanuts. The role of the trade union organizations is important to create a good environment for employed workers but in the country organizations are inefficient in the country to address the potential labor conflicts of migrants. It is difficult for migrants with low education and less experience to understand the benefits and regulations protecting them from employers. Therefore, effective management to control migration is needed to help the vulnerable migrants to protect their rights responding to those who have decided to stay in their origin place. This study recommends the government to review some of the policies of the urban employment. If the objective is to promote, there must be enough evidence to do so simply by protecting and promoting the rights of the migrants in the destinations. It is important to address the following in the policy; the level of welfare of the workers before departure, effective information about the migration and the negative effects involved in the whole process of migration and the responsibility of the administration to minimize the migration must be clearly stated in the law .The integration of the community development plan with the migration process is necessary to handle the pressure caused by migrants. The intervention policy must reflect the manpower established to present the context. The incentive of free tax to those who have decided to stay in rural areas is a significant strategy to reduce the outflow, so whenever possible the government should opt to use such a strategy. Cooperating with social pattern as well as the migrants themselves is particularly important to develop appropriate policies and programs which in turn will help to reduce the cost of implementation. It is also desirable to form strong structures responsible to organize the formulation of the migration policy.

\section{References}

Africa-Europe Summit (2000). The migration policy framework for African, North Ordinary Session, June 25-29, Banjul, Gambia 


\section{Macrothink}

Business and Economic Research ISSN 2162-4860 2014, Vol. 4, No. 1

Becker, G. M., Mills, E. S., \& Williamson, J. G. (1986). Modeling India migration and city growth 1960-2000: Economic Development and Cultural Change. 35, 1-33. http://dx.doi.org/10.1086/451571

Behrman, J. R., \& Birdsall, N. (1983). The quality of schooling: quantity alone is misleading: American Economic Review, 73, 928-946

Burke, M. (1970). Land reform and its effect upon production and productivity with Lake Titicaca region, Economic Development and Cultural Change, 18(3), Apr, 410-450. http://dx.doi.org/10.1086/450441

Byerlee, D., \& Eicher, C. K. (1974). Rural employment, migration and economic development: theoretical issue and empirical evidence from Africa: The place of Agriculture in the Development of the Developing Countries, Ed., By E.A.G. Robinson (London: Macmillan)

Fields, G. S. (1975). Rural-urban migration, urban unemployment and underemployment and job search activity in LDC's, Journal of Development Economies. 2, 165-187. http://dx.doi.org/10.1016/0304-3878(75)90014-0

Findley, S. E. (1981). Rural development programs: planned versus actual migration outcomes in population distribution policies in development planning studies, No.75 Department of International Economic and Social Affairs, United Nations, New York

Greene, W. H. (2003). Economic analysis, 3rd Edition, Prentice Hall Internal EditionHarris, J and Todaro, M (1970). Migration, unemployment and development: a two sector analysis, American Economic Review, 60,126-142

Henderson, J. V. (1986). Urbanization in a developing country: city size and population composition, Journal of Development Economics, 22, 269-293. http://dx.doi.org/10.1016/0304-3878(86)90132-X

Hugo, G. J. (1981b). Road transport, population mobility and development in Indonesia, in G.W. Jones and H. V. Richter, Eds, population mobility and development: Southern Asia and the Specific Development Studies Monograph, No.27 (Australian National University Canberra)

Hugo, G. (1995). International labor migration and the family: some observations from Indonesia, Asia Pacific Migration Journal, 4(2/3), 273-301

Katz, E., \& Stark, O. (1986a). Labor migration and risk aversion in less developed countries, Journal of Labor Economics, 4,134-49. http://dx.doi.org/10.1086/298097

Khandher, A., \& Rashid, A. (1995). Wage subsidy and full-employment in a dual economy with open employment and dual labor, Journal of Development Economics, 48(1), 205-23. http://dx.doi.org/10.1016/0304-3878(95)00035-6

Lavell, A. M. (1972). Regional industrialization in Mexico: some policy considerations, Regional Studies, 6, Sep, 343-362. http://dx.doi.org/10.1080/09595237200185291

Lee, Y. L. (1970). Population and settlement in Sarawak, Singapore, Asia Pacific Press 


\section{Macrothink}

Business and Economic Research ISSN 2162-4860 2014, Vol. 4, No. 1

Lewis, W. (1954). Economic development with unlimited supplies for labor, Manchester School of Economics and Social Studies, 22,139-91

Lin, J. (1998). Reconstructing, Chinatown ethnic enclave, global change. Minneapolis: University of Minnesota Press.

Lockheed, M. E., Janison, D. R., \& Lau, L. J. (1980). Farmer education and farm efficiency: a survey, Economic Development and Cultural Change, 29, 37-76. http://dx.doi.org/10.1086/451231

Lucas, R. (1997). Internal migration in developing countries, In Rosenzweig \& Stark Eds.; Handbook of Population and Family Economics, Northland, Elsevier, Vol. 1B, Chapter 13, pp. 721-98. http://dx.doi.org/10.1016/S1574-003X(97)80005-0

Mbonile, M. J. (1994b). Trading center and development of a remote rural district of Tanzania, Review of African Political Economy, 59, 7-20. http://dx.doi.org/10.1080/03056249408704033

Mbonile, M. J. (1996). The determinants of migration in Tanzania: the case of Makete district, University of Dar es Salaam Institute of Resources Assessment, New Series Paper 1996

McDonald, L., \& McDonald, J. S. (1968). Motives and objectives of migration: selective migration and preferences toward rural and urban life, Social and Economic Studies, 17, Dec, 417-434

Modi, J. R. (1982). Narrowing regional disparities by fiscal incentives, Finance and Development, 19, 34-37

Narayana, N. S, Darikh, K. S., \& Srinivas, T. N.(1988). Rural works programs in India: costs and benefits, Journal of Development Economics, 29,131-151. http://dx.doi.org/10.1016/0304-3878(88)90032-6

Ng, R. (1968). Land settlement projects in Thailand, Geography, 53, 1979-182

Oberai, A. S. (1983). State policies and internal migration: Studies in Market and Planned Economies, London: Croom Helm

Ping, H., \& Pieke, F. (2003). China migration country study, Paper Prepared for the Regional Conference on Migration, Development and Pro-Poor Policy Choices in Asia, June 22-24

Rosenzweign, M. R., \& Wolpin, K. I. (1988). Migration selectivity and the effects of public programs, Journal of Public Economics, $37 . \quad 265-289$. http://dx.doi.org/10.1016/0047-2727(88)90042-4

Sandhu, K. S. (1964). Emergency settlement in Malaya, Journal of Tropical Geography, 18, $157-183$

Simkins, P., \& Wernstedt, F. (1971). Philippine migration: the settlement of the Digos- Padada Valley, Davao Province. New Haven, Yale University of Southeast Asia Studies, Monograph Series No.16

Simmons, A. B. (1981). A review and evaluation of attempts to constrain migration to select 


\section{Macrothink}

Business and Economic Research ISSN 2162-4860 2014, Vol. 4, No. 1

urban centres and regions in population distribution policies in development planning: population studies, No.75. Department of International Economic and Social Affairs, United Nations, New York

Skeldon, R. (2003a). Migration and poverty, Paper Prepared for the Conference on African Migration and Urbanization in Comparative Perspective, Johannesburg, South Africa, June 4-7.

Skeldon, R. (2003b). Migration and migration policy in Asia: A Synthesis of Selected Cases Paper Prepared for the Regional Conference on Migration, Development and Pro-Poor Choices in Asia, June 22-24. http://dx.doi.org/10.1002/psp.385

Skeldon, R. (2007). Interlinkages between internal and international migration in the Asia region, Population, Space and Place, 12(1), 15-30

Speare Jr. A., \& Harris, J. (1986). Education, earnings and migration in Indonesia, Economic Development and Cultural Change, 34, 223-244. http://dx.doi.org/10.1086/451525

Waddington, C. (2003). National policy and internal migration, Paper presented at the Regional Conference on Migration, Development and Pro-Poor Policy Choices in Asia, June 22-24, 2003.

Wertheim, W. F. (1964). Inter-island migration in Indonesia: In East-West Parallels, Sociological Approaches to Modern Asia, The Hague Van Hoeye

Wheaton, W., \& Shishido, H. (1981). Urban concentration, agglomeration economies and the level of economic development. Economic Development and Cultural Change, 30, 17-30. http://dx.doi.org/10.1086/452537

Widjojo, N. (1970). Population trends in Indonesia. Ithaca, Cornell University Press

Zachariah, K. C. (1969). Internal migration and urbanization, In Barrie, W.E, and Cameron, M., ed; Population Change: Asia and Oceania. Proceeding of Sydney Conference Australia, 21-25, August, 1967, International Union for the Scientific Study of Population Canberra, Australia, Australian National University, Department of Demography, 98-112.

\section{Copyright Disclaimer}

Copyright reserved by the author(s).

This article is an open-access article distributed under the terms and conditions of the Creative Commons Attribution license (http://creativecommons.org/licenses/by/3.0/). 